\title{
Human B1 Cells are the Main Blood Group A-Specific B Cells That Have a Moderate Correlation With Anti-A Antibody Titer
}

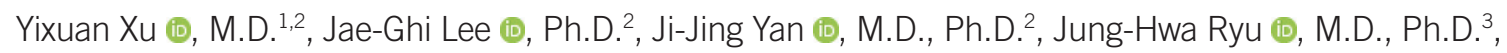
Songji Xu (1), M.D., Ph.D. ${ }^{1}$, and Jaeseok Yang ${ }^{10}$, M.D., Ph.D. ${ }^{3,4}$

${ }^{1}$ Department of Preventive Medicine, Yanbian University College of Medicine, Yanji, Jilin, People's Republic of China; ${ }^{2}$ Biomedical Research Institute, ${ }^{3}$ Transplantation Center, and ${ }^{4}$ Department of Surgery, Seoul National University Hospital, Seoul, Korea

Background: Anti-carbohydrate antibody responses, including those of anti-blood group ABO antibodies, are yet to be thoroughly studied in humans. Because anti-ABO antibodymediated rejection is a key hurdle in ABO-incompatible transplantation, it is important to understand the cellular mechanism of anti-ABO responses. We aimed to identify the main human $B$ cell subsets that produce anti-ABO antibodies by analyzing the correlation between $B$ cell subsets and anti-ABO antibody titers.

Methods: Blood group A-binding B cells were analyzed in peritoneal fluid and peripheral blood samples from 43 patients undergoing peritoneal dialysis and 18 healthy volunteers with blood group B or O. The correlation between each blood group A-specific B cell subset and anti-A antibody titer was then analyzed using Pearson's correlation analysis.

Results: Blood group A-binding B cells were enriched in $\mathrm{CD} 27^{+} \mathrm{CD} 43^{+} \mathrm{CD} 1 \mathrm{c}^{-} \mathrm{B} 1, \mathrm{CD}^{+}$ $\mathrm{B} 1, \mathrm{CD} 11 \mathrm{~b}^{+} \mathrm{B} 1$, and $\mathrm{CD} 27^{+} \mathrm{CD} 43^{+} \mathrm{CD} 1 \mathrm{c}^{+}$marginal zone-B1 cells in peripheral blood. Blood group A-specific $\mathrm{B} 1$ cells $(P=0.029$ and $\mathrm{R}=0.356$ for $\operatorname{lgM} ; P=0.049$ and $\mathrm{R}=0.325$ for IgG) and marginal zone-B1 cells $(P=0.011$ and $\mathrm{R}=0.410$ for $\operatorname{lgM})$ were positively correlated with anti-A antibody titer. Further analysis of peritoneal B cells confirmed B1 cell enrichment in the peritoneal cavity but showed no difference in blood group A-specific B1 cell enrichment between the peritoneal cavity and peripheral blood.

Conclusions: Human B1 cells are the key blood group A-specific B cells that have a moderate correlation with anti-A antibody titer and therefore constitute a potential therapeutic target for successful ABO-incompatible transplantation.

Key Words: Anti-ABO antibodies, Blood group A antigen, Human B1 cells, Human marginal zone B cells, Peritoneal B cells
Received: March 27, 2019

Revision received: June 6, 2019

Accepted: July 31, 2019

\section{Corresponding author:}

Jaeseok Yang, M.D., Ph.D.

Transplantation Center, Seoul National University Hospital, 101 Daehak-ro, Jongno-gu, Seoul 03080, Korea

Tel: +82-2-2072-4128

Fax: $+82-2-2072-4129$

E-mail: jcyjs@snu.ac.kr

\section{Co-corresponding author:}

Songji Xu, M.D., Ph.D.

Department of Preventive Medicine,

Yanbian University College of Medicine, Yanji 133002, Jilin, People's Republic of

China

Tel: +86-433-2435271

Fax: +86-433-2435271

E-mail: yrge@ybu.edu.cn

\section{(c) (i) (5)}

(c) Korean Society for Laboratory Medicine This is an Open Access article distributed under the terms of the Creative Commons Attribution Non-Commercial License (http://creativecommons.org/licenses/by-nc/4.0) which permits unrestricted non-commercial use, distribution, and reproduction in any medium, provided the original work is properly cited.

\section{INTRODUCTION}

Organ transplantation is the treatment of choice for patients with end-stage organ failure. However, there is a huge imbalance between the supply and demand of organs. ABO-incompatible transplantation is an emerging solution to this problem and is expected to increase organ supply by as much as 25\% [1-3]. Antibody-mediated rejection, caused by anti-ABO antibodies, has been the most challenging hurdle for $\mathrm{ABO}$-incompatible transplantation. $\mathrm{ABO}$ blood group antigens are carbohydrate antigens, and anti-ABO antibody responses are known to show different patterns from anti-HLA antibody responses, which are 
a part of the conventional anti-peptide antibody response [4]. Anti-ABO antibody responses are "T-independent" antibody responses that do not require the involvement of $\mathrm{T}$ cells. However, it remains unclear which $B$ cell subsets are the main cells that produce anti-ABO antibodies and whether those $B$ cells require help from innate-type T cells [5].

Previous studies have shown that B1 cells produce anti-ABO antibodies [6, 7]. Murine B1 cells have innate phenotypes, express $\mathrm{CD} 11 \mathrm{~b}$ and surface IgM, and mainly reside in the peritoneal cavity [8]. These murine B1 cells are sub-divided into CD5+ B1a cells and CD5- B1b cells [8]. In contrast to the well-defined phenotypes of mouse B1 cells, the phenotype of human B1 cells is unclear. $\mathrm{A}$ recent study proposed that $\mathrm{CD} 2 \mathrm{O}^{+} \mathrm{B}$ cells that simultaneously express CD43 and CD27 are B1 cells [9]. These cells continuously secrete $\operatorname{lgM}$, maintain tonic signaling, and can help $T$ cell activation and are therefore functionally similar to murine B1 cells [9]. Similar to murine B1 cells, human B1 cells are subdivided based on the expression of CD5 and CD11b [10, 11]. Marginal zone $B(M Z B)$ cells are another type of innate $B$ cells that are involved in the production of anti-alpha-Gal, a type of anti-carbohydrate antibody [12]. Human MZB cells are also present in the spleen and peripheral blood and express both CD27 and CD1c $[13,14]$. Therefore, MZB cells may constitute another candidate for the production of anti-human $\mathrm{ABO}$ antibodies together with $\mathrm{B} 1$ cells.

We identified B1 and MZB cell populations in human peripheral blood according to previous classification methods [9, 14]. This is the first study to investigate the correlation between human blood group A-specific B cells expressing and producing anti-A antibodies and anti-A antibody levels in the peripheral blood, and to identify the main human $B$ cell subset that produces anti-A antibodies.

\section{METHODS}

\section{Sample preparation}

The study was prospectively performed between 2014 and 2018 at Seoul National University Hospital, Seoul, Korea, in accordance with the Declaration of Helsinki, and its protocol was approved by Seoul National University Hospital's Institutional Review Board (H-1411-020-623) Ten milliliters of peripheral blood were extracted from 43 healthy volunteers, 13 kidney transplant patients, and 18 peritoneal dialysis patients with blood group $\mathrm{B}$ or $\mathrm{O}$ after they provided informed consent. Peripheral blood of $A B O-i n-$ compatible kidney transplant patients was extracted before $(\mathrm{N}=8)$ and one yr after $(\mathrm{N}=10)$ transplantation. One liter of peritoneal fluid was also collected from peritoneal dialysis patients. Peritoneal cells were obtained by centrifugation of whole fluid obtained from the peritoneal dialysis patients when their peritoneal cavity was washed, two weeks after catheter insertion. Peripheral blood mononuclear cells (PBMCs) were isolated by gradient centrifugation using Ficoll (GE Healthcare, Cleveland, OH, USA). PBMCs and peritoneal cells were subjected to red blood cell-lysis using BD Pharm Lyse (BD Biosciences, San Diego, CA, USA).

\section{Flow cytometric analysis}

PBMC and peritoneal cells were stained with the following antihuman antibodies: blood type (tri)- PAA-fluor (GlycoTech, Gaithersburg, MD, USA), anti-CD20 (L27), anti-CD27 (M-T271), antiCD43 (MEM-59), anti-CD5 (L17F12), anti-CD11b (ICRF44), antiCD1c (L161) (BioLegend, San Diego, CA, USA). Flow cytometric analyses were performed using a BD FACS Canto II flow cytometer (BD Biosciences), and data was analyzed using FlowJo (Tree Star, Ashland, OR, USA). Briefly, at least $1 \times 10^{6}$ PBMCs and peritoneal cells were subjected to FACS acquisition. Next, approximately $1-5 \times 10^{5}$ singlet lymphocytes were acquired based on the forward scatter (FSC)-A, FSC-H, and side scatter (SSC)A. The lymphoid compartment contained approximately 15-30\% $\mathrm{CD} 2 \mathrm{O}^{+} \mathrm{B}$ cells. Based on a previous classification strategy [9], the $\mathrm{CD} 2 \mathrm{O}^{+} \mathrm{B}$ cells were divided into naïve $\mathrm{B} 2\left(\mathrm{CD}^{-} 3^{-} \mathrm{CD} 27^{-}\right)$, memory B2 $\left(\mathrm{CD} 27^{+} \mathrm{CD} 43^{-} \mathrm{CD} 1 \mathrm{c}^{-}\right), \mathrm{B} 1\left(\mathrm{CD} 2 \mathrm{O}^{+} \mathrm{CD} 27^{+} \mathrm{CD} 43^{+} \mathrm{CD} 1 \mathrm{c}^{-}\right)$, MZB $\left(\mathrm{CD} 27^{+} \mathrm{CD} 43^{-} \mathrm{CD} 1 \mathrm{C}^{+}\right)$, and marginal zone-B1 (MZ-B1, $\mathrm{CD} 27^{+} \mathrm{CD} 43^{+} \mathrm{CD} 1 \mathrm{C}^{+}$) cells according to $\mathrm{CD} 27, \mathrm{CD} 43$, and $\mathrm{CD} 1 \mathrm{C}$ expressions (Fig. 1A, upper panel). $C D 27^{+} \mathrm{CD} 43^{+} \mathrm{B} 1$ cells were

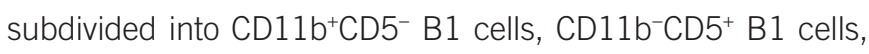
and $\mathrm{CD} 11 \mathrm{~b}^{+} \mathrm{CD} 5^{+} \mathrm{B} 1$ cells based on $\mathrm{CD} 5$ and $\mathrm{CD} 11 \mathrm{~b}$ expressions (Fig. 1B, upper panel) [10, 11]. Next, blood group A-specific $B$ cells capable of binding to the blood group $A$ antigenFluorescein isothiocyanate (FITC) complex were gated from total B cells (Fig. 1A, lower panel; Fig. 1B, lower panel). Similarly, blood group A-specific B cells were divided into $B$ cell subsets according to CD27, CD43, CD1c, CD5, and CD11b expressions. According to these classification strategies, the proportions of each $B$ cell subset among total and blood group A-specific B cells, and the proportion of blood group A-specific $B$ cells among each $B$ cell subset were analyzed (Fig. 2).

\section{Measurement of anti-blood group A antibody titers}

A gel card method (ID-System DiaMed; Bio-Rad, Hercules, CA, USA) was used to measure human blood group A-specific IgM and IgG [15]. Briefly, $50 \mu \mathrm{L}$ of $0.8 \%$ red blood cells (RBCs) and $25 \mu \mathrm{L}$ of serially diluted serum samples were added to the gel 

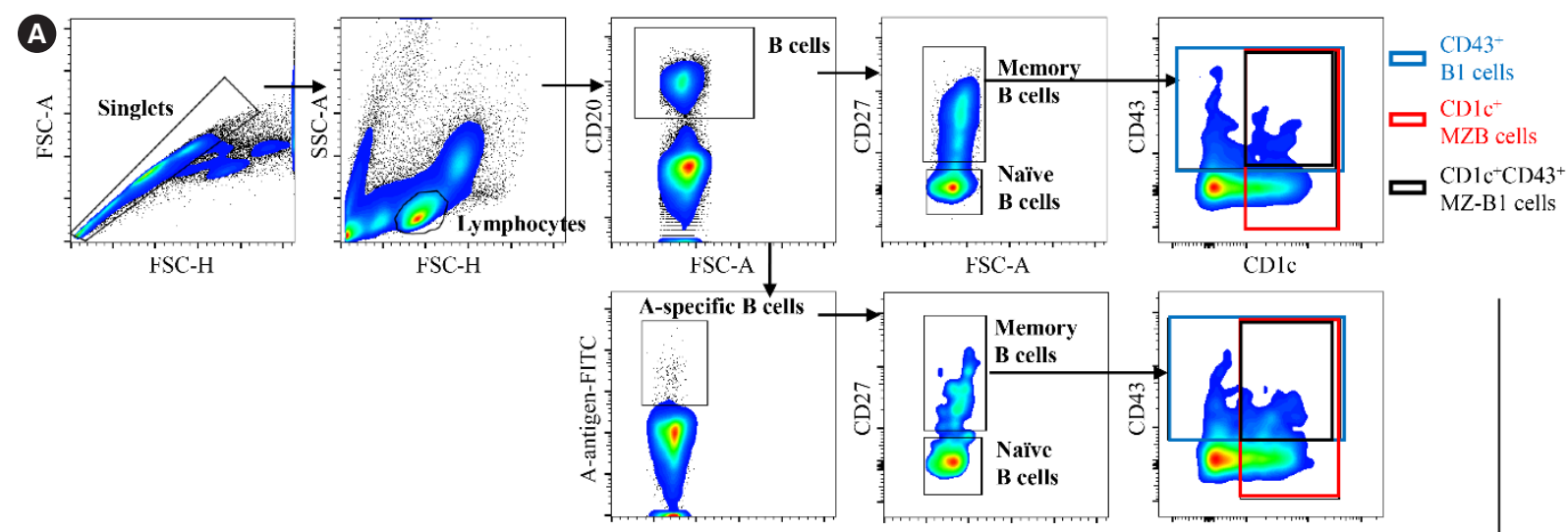

FSC-A

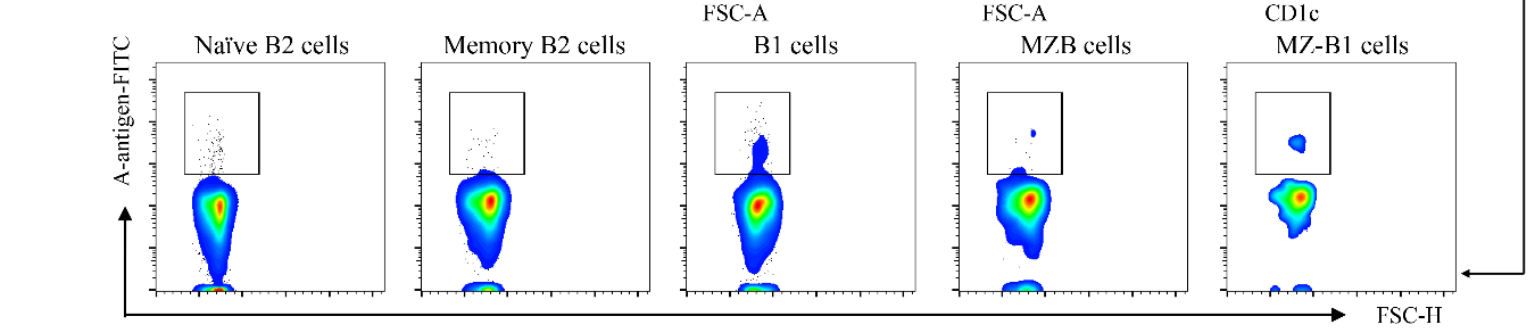

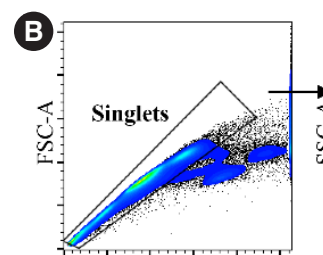

FSC-H

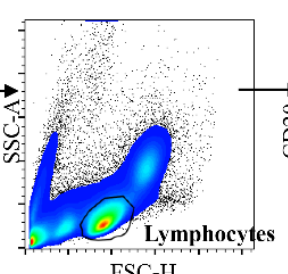

FSC-II

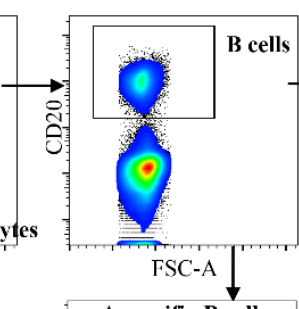

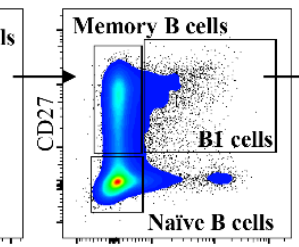

CD43
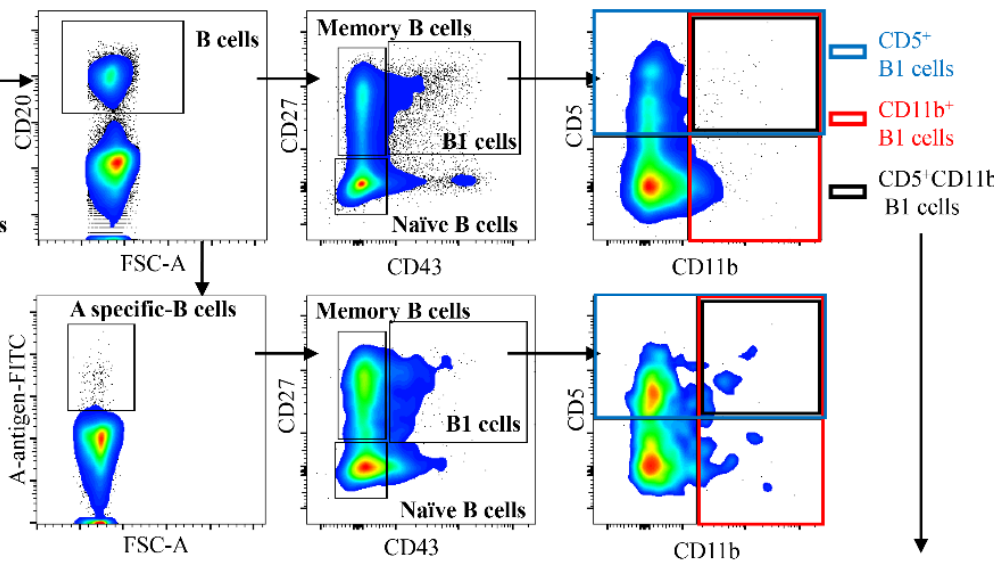

CD11b

B1 cells
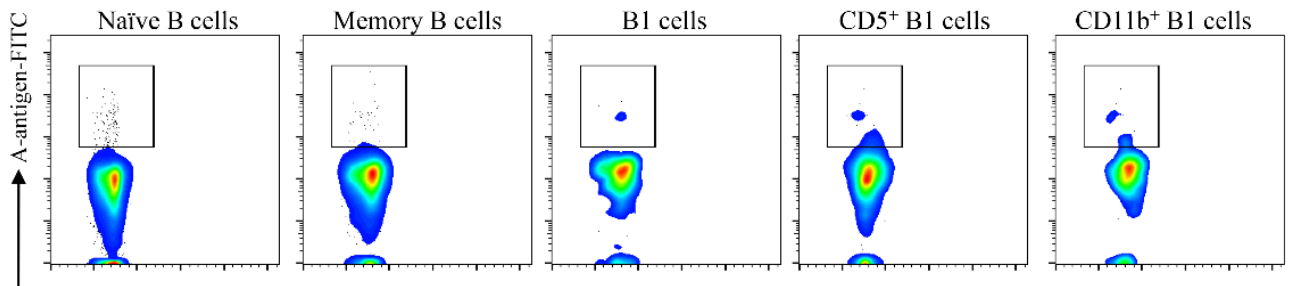

$\mathrm{CD}^{+} \mathrm{CD} 11 \mathrm{~b}^{+} \mathrm{B} 1 \mathrm{ce}$

Fig. 1. Gating strategy for naïve, memory, marginal zone, B1 and marginal zone-B1 B cells and B1 subpopulations. (A) For analysis of B cells in peripheral blood, singlet blood lymphocytes were gated for total $\mathrm{CD} 2 \mathrm{O}^{+} \mathrm{B}$ cells or ' $\mathrm{A}$ ' antigen-capturing, blood group A-specific CD20+ $\mathrm{B}$ cells. Next, the $\mathrm{CD} 2 \mathrm{O}^{+} \mathrm{B}$ cells were divided into various subsets. (B) For analysis of B1 cell subpopulations in peripheral blood, $\mathrm{CD} 27^{+} \mathrm{CD} 43^{+} \mathrm{B} 1$ cells were subdivided into various subpopulations based on $\mathrm{CD} 5$ and $\mathrm{CD} 11 \mathrm{~b}$ expressions.

Abbreviations: MZB, marginal zone B cells; MZ-B1, marginal zone-B1 cells.

card and incubated at room temperature $\left(20-25^{\circ} \mathrm{C}, \operatorname{lgM}\right)$ or $37^{\circ} \mathrm{C}$ (IgG) for 15 minutes. After centrifugation for 10 minutes, the presence of trapped agglutinates on the top of or dispersed throughout the gel matrix was considered a positive result. A single sed- iment found at the bottom of the gel matrix was considered a negative result. The highest dilution point that showed a positive result was considered the final titer. 

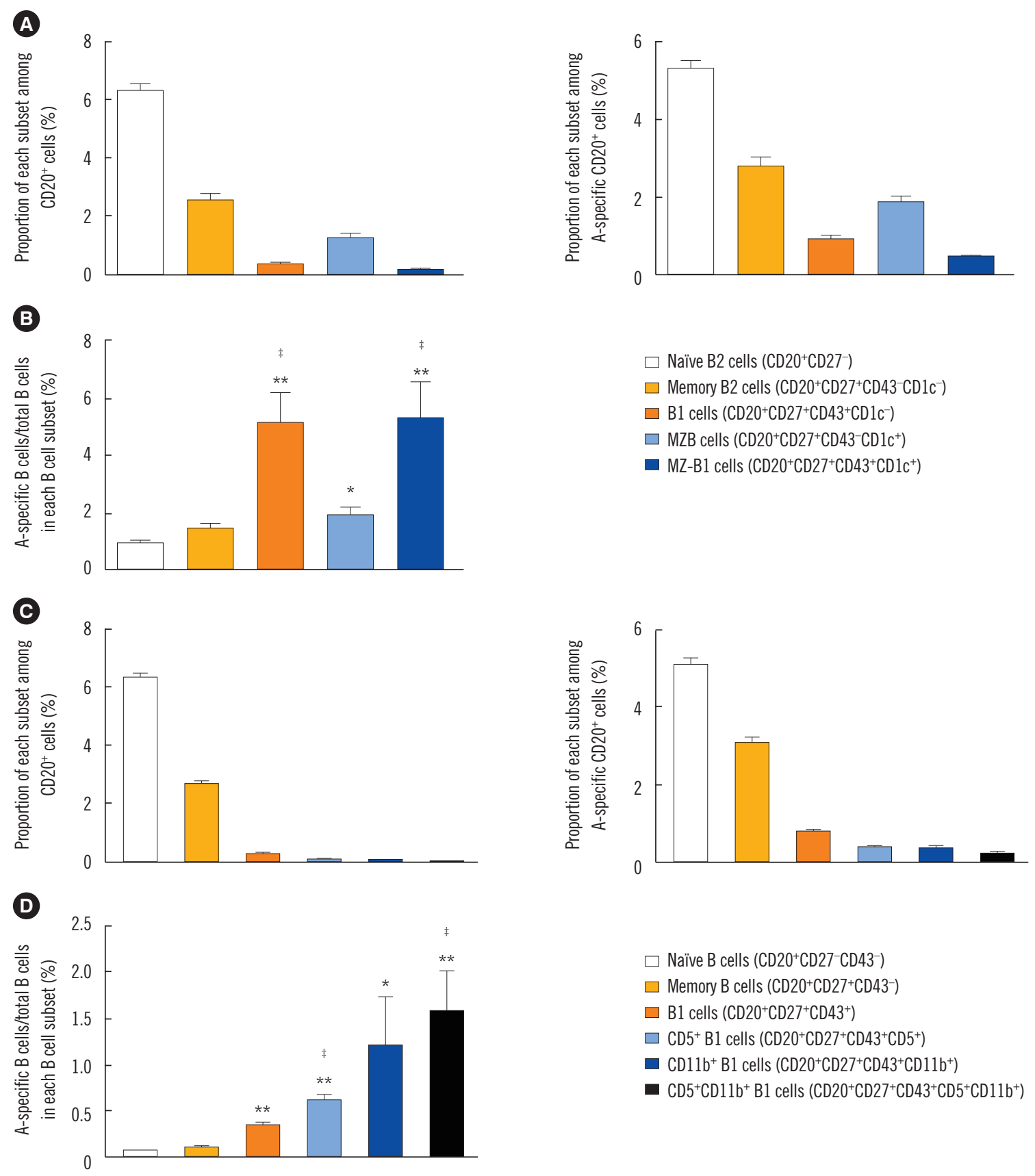

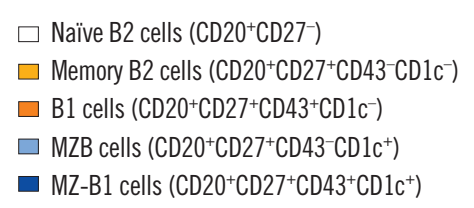

Fig. 2. The frequency of each blood group A-specific $B$ cell subset. (A) The proportion of each $B$ cell subset among the total $C D 2 O^{+} B$ cells (left panel) and A-specific CD20+ B cells (right panel). (B) The proportion of blood group A-specific B cells among each B cell subset. ${ }^{*} P<0.05$, ${ }^{* *} P<0.01$ compared with the naîve B2 cell group. ${ }^{\ddagger} P<0.01$ compared with the memory B2 cell group. (C) The proportions of each B1 cell subset among the total $\mathrm{CD} 2 \mathrm{O}^{+} \mathrm{B}$ cells (left panel) and A-specific $\mathrm{CD} 2 \mathrm{O}^{+} \mathrm{B}$ cells (right panel). (D) The proportions of blood group A-specific $\mathrm{B}$ cells among each B1 cell subset. ${ }^{*} P<0.05$, ${ }^{* *} P<0.01$ compared with the naïve and memory B2 cell group. ${ }^{\dagger} P<0.05,{ }^{{ }^{\ddagger}} P<0.01$ compared with the $\mathrm{B} 1$ cell group. The results are expressed as mean $\pm \mathrm{SEM} ; \mathrm{N}=30-45$ per group.

Abbreviations: FITC, fluorescein isothiocyanate; FSC, forward scatter; MZB, marginal zone B cells; MZ-B1, marginal zone-B1 cells; SEM, standard error of the mean.

\section{Statistical analysis}

Data were presented as mean \pm standard error of the mean (SEM) or median with range. Both age and proportions of B cell sub- sets followed a normal distribution, but titers of anti-blood group A antibodies did not. Continuous variables were analyzed using Student's t-tests, and correlations were analyzed using Pearson's 
correlation analysis. Degree of correlation was regarded as weak if the correlation coefficient $(R)$ was $<0.4$, moderate if $R$ was between 0.4 and 0.6 , and strong for $R \geq 0.6$ [16]. $P<0.05$ was considered statistically significant. All analyses were performed using SPSS (version 20.0, IBM Corporation, Armonk, NY, USA).

\section{RESULTS}

Demographic characteristics of study subjects and anti-A antibody titers are summarized in Table 1. Blood group A-specific B cells were enriched in B1 and MZ-B1 cells in peripheral blood. We first assessed the frequency of B1 cells and MZB cells in the peripheral blood of the healthy volunteers. $\mathrm{CD} 43^{+} \mathrm{B} 1$ and $\mathrm{CD} 1 \mathrm{C}^{+}$ MZB cells accounted for $3.27 \pm 0.29 \%$ and $12.97 \pm 1.03 \%$ of the entire $\mathrm{CD} 27^{+} \mathrm{B}$ cell population, respectively (Figs. $1 \mathrm{~A}$ and 2A). Interestingly, MZ-B1 cells expressing both CD43 and CD1C $(1.68 \pm 0.26 \%)$ were also identified (Fig. $2 A$, left panel). When each $B$ cell subset was measured among the blood group Aspecific $B$ cells, the overall trend was similar to the proportion of each B cell subset among the total B cells (Fig. 2A, right panel). Analysis of the proportion of blood group A-specific $B$ cells among each $B$ cell subset suggested that the blood group A-specific $B$ cells in the B1 $(5.13 \pm 1.06 \%)$ and MZ-B1 $(5.27 \pm 1.28 \%)$ cells were significantly higher than those in naive $(0.96 \pm 0.11 \%)$ and memory (1.45 $\pm 0.18 \%)$ B2 cells (Fig. 2B). The proportion of blood group A-specific $B$ cells was also slightly higher in the MZB cells than in naïve or memory B2 cells (Fig. 2B).

Next, the CD43-expressing B1 cells were subdivided based on CD5 and CD11b expression (Fig. $2 \mathrm{C}$ ). When the proportion of blood group A-specific B cells among each B1 cell subset was analyzed, the blood group $A$-specific $B$ cells were enriched in the total $\mathrm{CD} 27^{+} \mathrm{CD} 43^{+} \mathrm{B} 1$ cells and $\mathrm{B} 1$ subpopulations, such as $\mathrm{CD}^{+}, \mathrm{CD} 11 \mathrm{~b}^{+}$and $\mathrm{CD}^{+} \mathrm{CD} 11 \mathrm{~b}^{+} \mathrm{B} 1$ cells, compared with naïve and memory B2 cells (Fig. 2D).

$B 1$ cells were the main blood group A-specific $B$ cells in ABOincompatible kidney transplant patients, in agreement with data obtained from healthy volunteers (Supplemental Data Fig. S1).

Taken together, these data confirmed that B1, MZB, and MZ$\mathrm{B} 1$ cells are present in peripheral blood and demonstrated that blood group A-specific B cells were enriched in B1 cells, including $\mathrm{CD}^{+}, \mathrm{CD} 11 \mathrm{~b}^{+}$, and $\mathrm{CD} 5^{+} \mathrm{CD} 11 \mathrm{~b}^{+} \mathrm{B} 1$ cells, as well as MZ-B1 cells.

\section{Correlation between the proportion of blood group}

\section{A-specific B cell subset and anti-A antibody titer}

The anti-A IgM and IgG titers of healthy volunteers were 1:16 (1:2-1:128) and 1:64 (1:2-1:1,512), respectively (Table 1). The anti-A IgM and IgG titers in blood group $\mathrm{O}$ donors were significantly higher than those in blood group $B$ donors (IgM, $P=0.012$; IgG, $P<0.01$, Table 1 ). There was no significant difference in the anti-A IgM or IgG titers between healthy volunteers and peritoneal dialysis patients.

When we examined the correlation between anti-A antibody titer and the proportion of blood group A-specific B cells within each $B$ cell subset, a weak positive correlation was observed between the anti-A IgM and IgG titers and $B 1$ cells $(P=0.029$ and $\mathrm{R}=0.356$ for IgM, Fig. $3 \mathrm{~A} ; P=0.049$ and $\mathrm{R}=0.325$ for lgG, Fig. 3B). The MZ-B1 cells showed a moderately positive correlation only with the anti-A IgM titer $(P=0.011$ and $R=0.410$, Fig. $3 A$ ), and the MZB cells showed a positive correlation trend with the anti-A antibody titer (Fig. 3A and 3B).

When the B1 cell subpopulations were analyzed, CD11b+ B1 cells were weakly correlated with the anti-A IgM titer $(P=0.027$,

Table 1. Characteristics of study participants

\begin{tabular}{lccc}
\hline & Peritoneal dialysis patients $(\mathrm{N}=18)$ & Healthy volunteers $(\mathrm{N}=43)$ & Kidney transplant patients $(\mathrm{N}=13)$ \\
\hline Age (yr, mean $\pm \mathrm{SEM})$ & $48.56 \pm 2.66$ & $41.72 \pm 1.70$ & $51.20 \pm 3.07$ \\
Sex (male, $\mathrm{N})$ & 6 & 20 & 8 \\
Blood group 0 (N) & 8 & 31 & 8 \\
Blood group B (N) & 10 & 12 & 5 \\
Anti-A IgM titer (median, range) & $1: 8(1: 4-1: 256)$ & $1: 16(1: 2-1: 128)$ & $1: 8(1: 1-1: 64)$ \\
Anti-A IgM titer in blood group 0 (median, range) & $1: 32(1: 4-1: 256)$ & $1: 32(1: 4-1: 128)$ & $1: 16(1: 1-1: 64)$ \\
Anti-A IgM titer in blood group B (median, range) & $1: 8(1: 4-1: 32)$ & $1: 8^{*}(1: 2-1: 64)$ & $1: 4(1: 1-1: 16)$ \\
Anti-A lgG titer (median, range) & $1: 16(1: 4-1: 256)$ & $1: 64(1: 2-1: 512)$ & $1: 32(1: 1-1: 128)$ \\
Anti-A IgG titer in blood group 0 (median, range) & $1: 64(1: 8-1: 512)$ & $1: 128(1: 8-1: 512)$ & $1: 8(1: 1-1: 64)$ \\
Anti-A IgG titer in blood group B (median, range) & $1: 8^{*}(1: 4-1: 32)$ & $1: 8^{\dagger}(1: 2-1: 128)$ & $1: 16(1: 1-1: 128)$
\end{tabular}

${ }^{*} \mathrm{P}<0.05$ in comparison between blood group $\mathrm{O}$ and blood group $\mathrm{B} ;{ }^{\dagger} \mathrm{P}<0.01$ in comparison between blood group $\mathrm{O}$ and blood group $\mathrm{B}$. Abbreviation: SEM, standard error of the mean. 


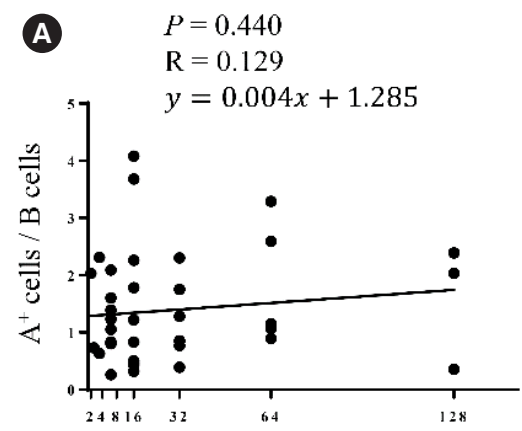

$\Lambda$ nti- $\Lambda$ antibody titer $(\operatorname{IgM})$
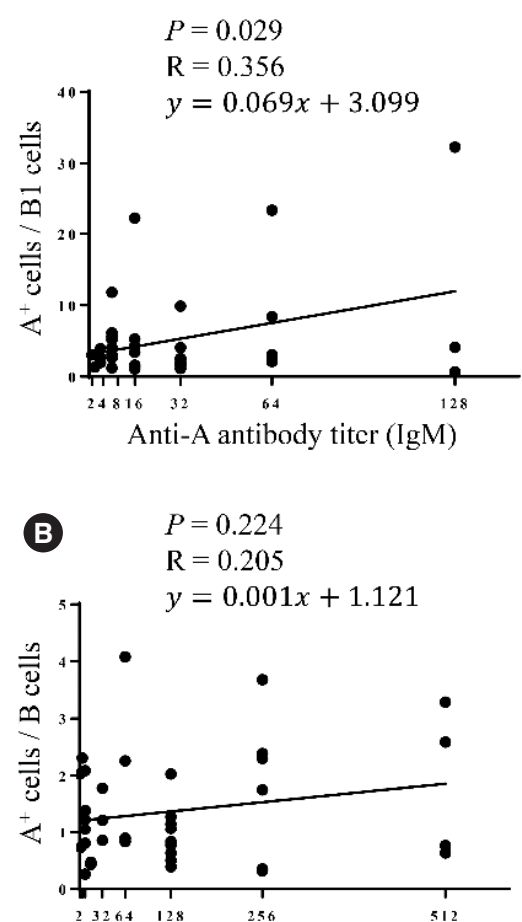

Anti-A antibody titer (IgG)

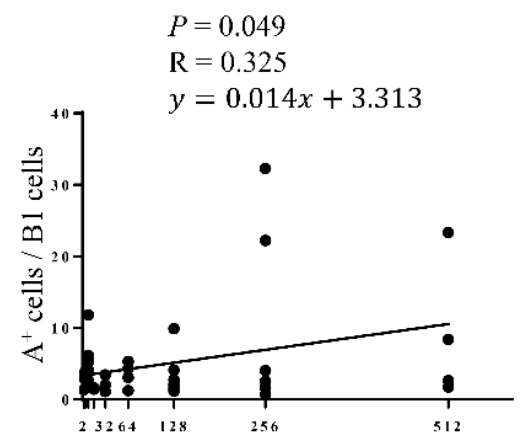

Anti-A antibody titer (IgG)

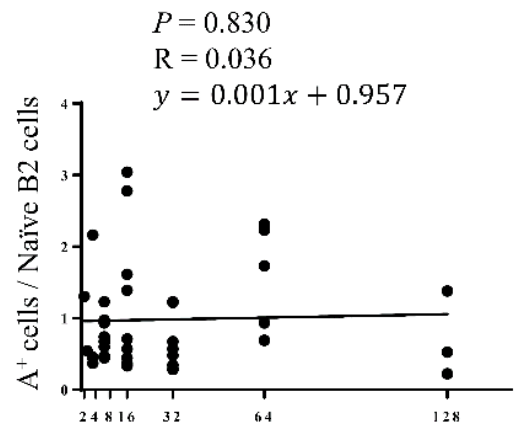

$\Lambda$ nti- $\Lambda$ antibody titer $(\operatorname{Ig} M)$

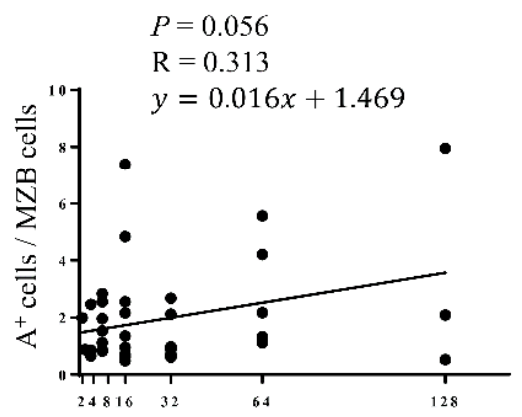

Anti-A antibody titer (IgM)

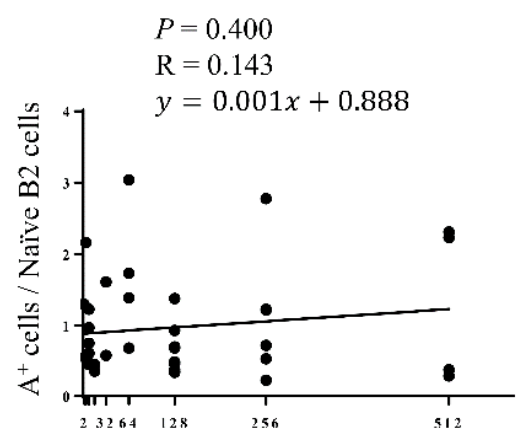

Anti-A antibody titer (IgG)

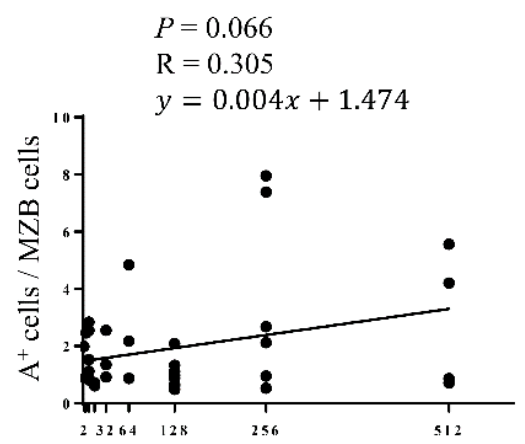

Anti-A antibody titer (IgG)

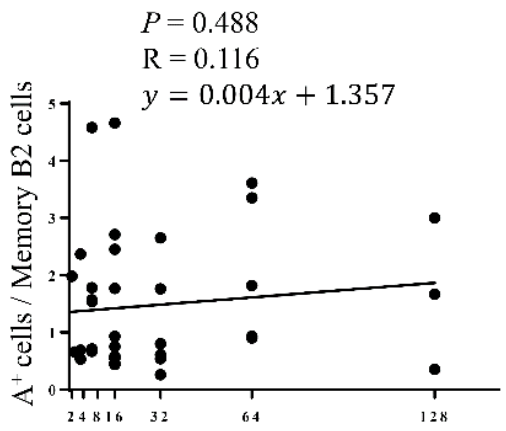

$\Lambda$ nti- $\Lambda$ antibody titer $(\lg M)$

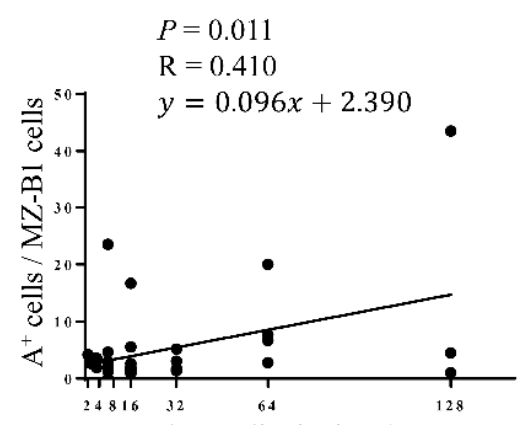

Anti-A antibody titer (IgM)

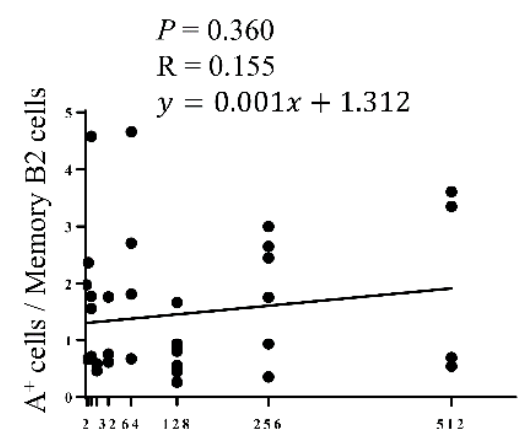

Anti-A antibody titer $(\operatorname{IgG})$

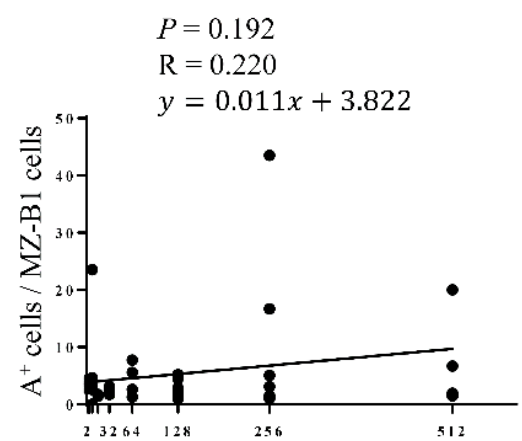

Anti-A antibody titer ( $\operatorname{IgG})$

Fig. 3. The correlation between the frequency of each $B$ cell subset and anti-blood group $A \lg M(A)$ and $\lg G(B)$ titer in the peripheral blood. The anti-A IgM titer was positively correlated with the frequency of $\mathrm{CD} 2 \mathrm{O}^{+} \mathrm{CD} 27^{+} \mathrm{CD} 43^{+} \mathrm{CD} 1 \mathrm{c}^{-} \mathrm{B} 1$ cells and $\mathrm{CD} 2 \mathrm{O}^{+} \mathrm{CD} 27^{+} \mathrm{CD} 43^{+} \mathrm{CD} 1 \mathrm{C}^{+} \mathrm{MZ}-$ $\mathrm{B} 1$ cells ( $\mathrm{B} 1$ cells, $P=0.029, \mathrm{R}=0.356$; $\mathrm{MZ}-\mathrm{B} 1$ cells, $P=0.011, \mathrm{R}=0.410$ ). The anti-A IgG titer was positively correlated with the frequency of $\mathrm{CD}_{20} \mathrm{C}^{\mathrm{C}} 27^{+} \mathrm{CD} 43^{+} \mathrm{CD} 1 \mathrm{C}^{-} \mathrm{B} 1$ cells $(P=0.049 ; \mathrm{R}=0.325)$.

Abbreviations: MZB, marginal zone B cells; MZ-B1, marginal zone-B1 cells; R, Pearson correlation coefficient. 


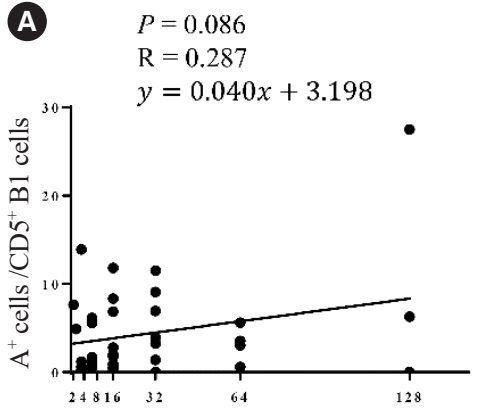

Anti-A antibody titer (IgM)

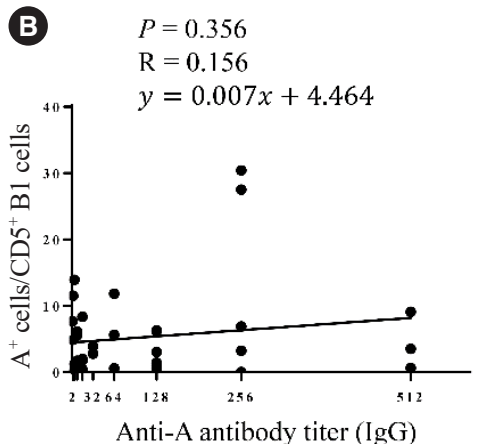

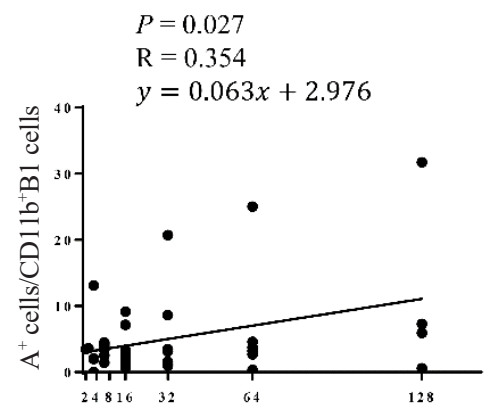

Anti-A antibody titer (IgM)

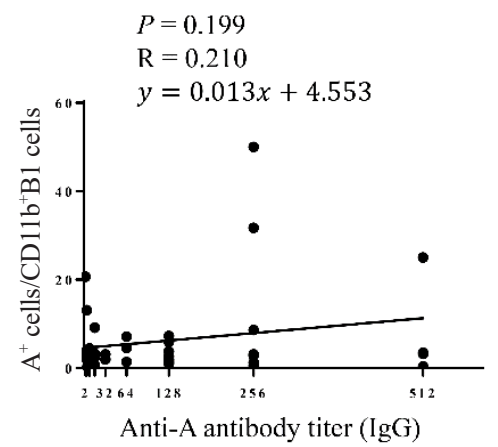

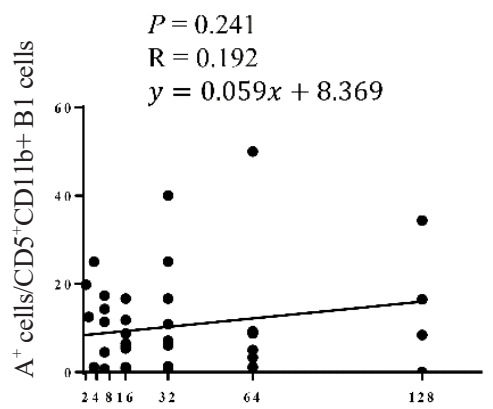

Anti-A antibody titer (IgM)

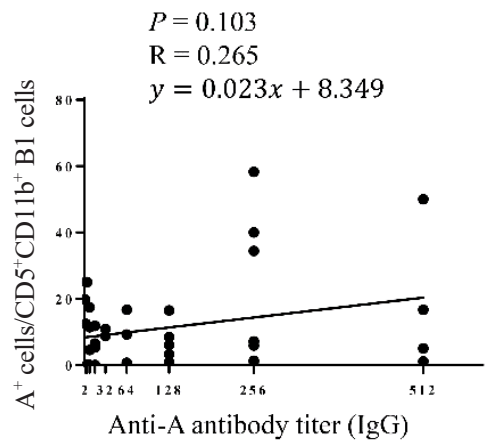

Fig. 4. The correlation between the frequency of each $B$ cell subset and anti-blood group $A \operatorname{lgM}(A)$ and IgG (B) titer in the peripheral blood. The frequency of each B1 subpopulation showed a positive correlation tendency with the anti-A IgM titer. Abbreviation: R, Pearson correlation coefficient.

$R=0.354$, Fig. $4 A$ ), while the $C D 5^{+} B 1$ cells showed only a trend of positive correlation with anti-A IgM titer $(P=0.086, \mathrm{R}=0.287$, Fig. 4A). There was no statistically significant correlation between individual B1 subpopulations and the anti-A IgG titer (Fig. 4B). Overall, blood group A-specific B1 cells were positively correlated with anti-A antibody titers.

Human B1 cell enrichment in the peritoneal cavity When we compared B cell subsets between peripheral blood and peritoneal cells, the proportions of total $\mathrm{B} 1, \mathrm{CD}^{+} \mathrm{B} 1, \mathrm{CD} 11 \mathrm{~b}^{+}$ $\mathrm{B} 1$, and $\mathrm{CD} 5^{+} \mathrm{CD} 11 \mathrm{~b}^{+} \mathrm{B} 1$ cells were higher in the peritoneal cavity than in peripheral blood, similar to the proportions in mice (Fig. 5A and 5B, left and middle panels). However, blood group A-specific $B$ cell enrichment did not differ between peripheral blood cells and peritoneal cells (Fig. 5A and 5B, right panels).

\section{DISCUSSION}

The present study showed that blood group A-specific B cells were enriched in $\mathrm{CD} 27^{+} \mathrm{CD} 43^{+} \mathrm{CD} 1 \mathrm{c}^{-} \mathrm{B} 1, \mathrm{CD} 11 \mathrm{~b}^{+} \mathrm{B} 1$, and $\mathrm{CD} 27^{+}$ $\mathrm{CD}^{+} 3^{+} \mathrm{CD} 1 \mathrm{C}^{+} \mathrm{MZ}-\mathrm{B} 1$ cells in peripheral blood, as well as in the peritoneal cavity and that A-specific B1, CD11 b $\mathrm{B} 1$, and MZ-
B1 cells were positively correlated with anti-A antibody titer in peripheral blood. Taken together, these data suggest that B1 cells are the key blood group A-specific B cells involved in the production of anti-blood group $\mathrm{A}$ antibodies.

In the current era of $\mathrm{ABO}$-incompatible transplantation, rituximab has been used to eradicate total $B$ cells and reduce anti$\mathrm{ABO}$ antibody titer, thereby suppressing anti-ABO antibody-mediated rejection [17]. However, non-specific depletion of broad $B$ cell subsets by rituximab increases opportunistic infection in ABO-incompatible transplant patients [17]. Based on our study, targeted therapy towards B1 cells, instead of total B cells, could be a promising strategy for reducing the anti-A antibody titer with fewer adverse effects.

In general, B1 cells continuously produce low affinity lgM without antigen stimulation [18]. Recent studies on B1 cells have shown that IgG can be produced without antigen stimulation, although IgG production levels are lower than in blasts [19]. Therefore, the positive correlation between the frequency of Aspecific B1 cells and anti-A IgM and IgG titers in our study suggests that B1 cells may be involved in the production of anti-A IgM and IgG. CD11b+ B1 cells have been reported to have weaker IgM secretory function but higher expression of CD86 than 

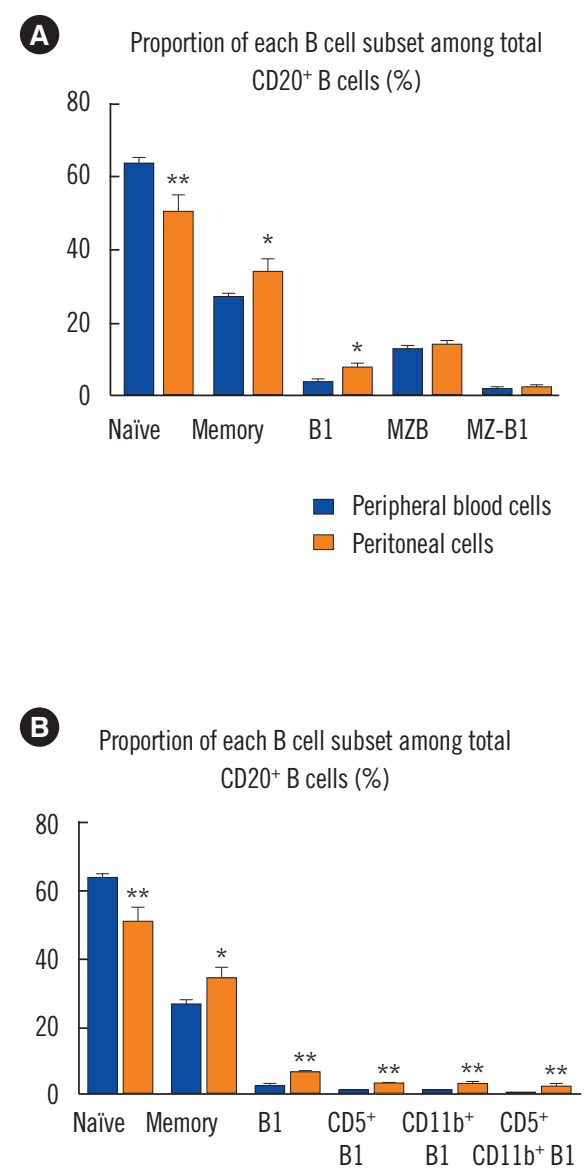
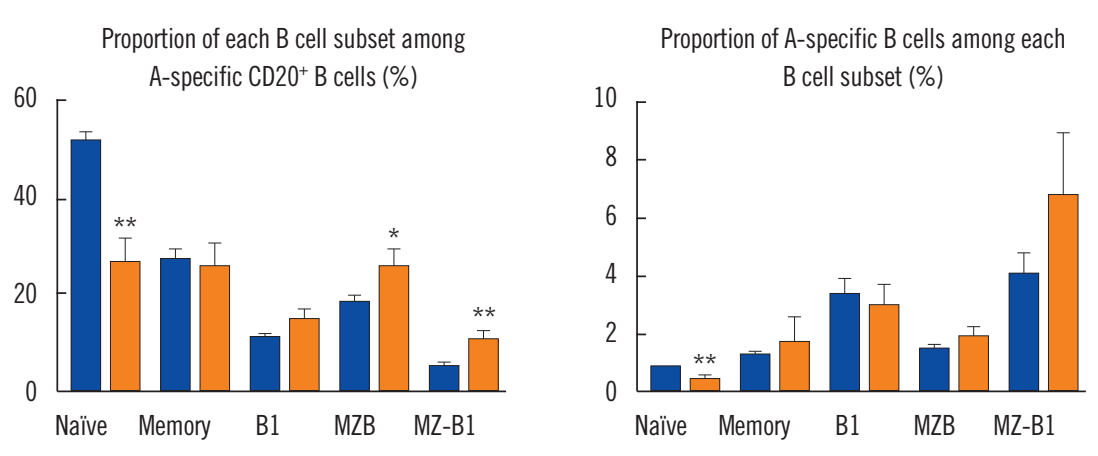

Naïve B2 cells (CD20+CD27-)

Memory B2 cells (CD20+CD27+CD43-CD1c-)

B1 cells (CD20 $\left.{ }^{+} \mathrm{CD} 27^{+} \mathrm{CD}^{+} 3^{+} \mathrm{CD} 1 \mathrm{c}^{-}\right)$

MZB cells (CD20 $\left.{ }^{+} \mathrm{CD} 27^{+} \mathrm{CD} 43^{-} \mathrm{CD} 1 \mathrm{C}^{+}\right)$

MZ-B1 cells (CD20 $\left.{ }^{+} \mathrm{CD} 27^{+} \mathrm{CD}^{+} 3^{+} \mathrm{CD} 1 \mathrm{C}^{+}\right)$
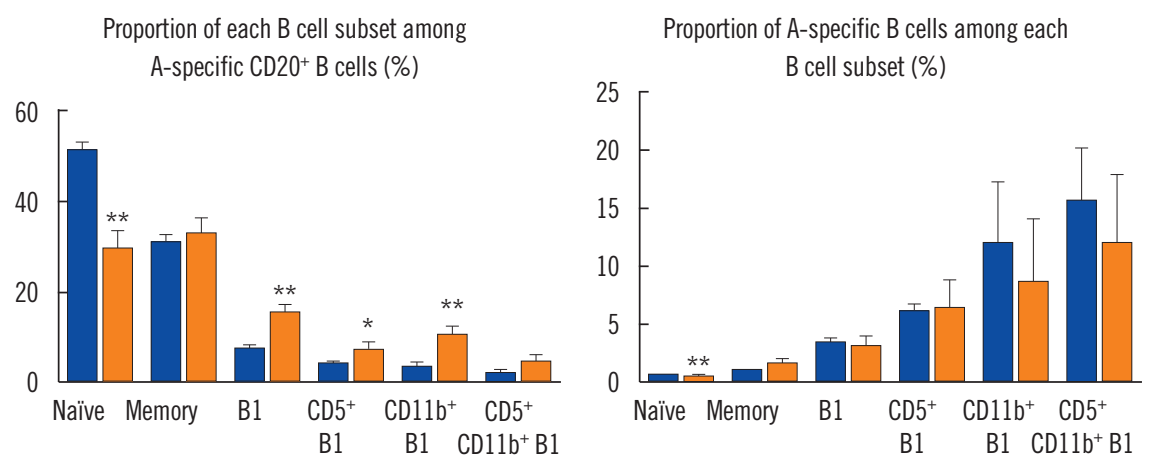

Naïve B2 cells (CD20+CD27-CD43-)

Memory B2 cells (CD20 $\left.{ }^{+} \mathrm{CD}_{27}{ }^{+} \mathrm{CD} 43^{-}\right)$

$\mathrm{B} 1$ cells $\left(\mathrm{CD} 2 \mathrm{O}^{+} \mathrm{CD} 27^{+} \mathrm{CD} 43^{+}\right)$

$\mathrm{CDF}^{+} \mathrm{B} 1$ cells $\left(\mathrm{CD} 2 \mathrm{O}^{+} \mathrm{CD} 27^{+} \mathrm{CD}_{3} 3^{+} \mathrm{CD}^{+}\right)$

$\mathrm{CD}_{11 b^{+}} \mathrm{B} 1$ cells (CD20 ${ }^{+} \mathrm{CD} 27^{+} \mathrm{CD} 43^{+} \mathrm{CD} 11 \mathrm{~b}^{+}$)

$\mathrm{CD}^{+}{ }^{+} \mathrm{CD} 11 \mathrm{~b}^{+} \mathrm{B} 1$ cells $\left(\mathrm{CD} 2 \mathrm{O}^{+} \mathrm{CD} 27^{+} \mathrm{CD} 43^{+} \mathrm{CDF}^{+} \mathrm{CD}^{+} 1 \mathrm{~b}^{+}\right)$

Fig. 5. B cell subsets and blood group A-specific $B$ cells analyzed using the (A) CD27, CD43, CD1c and (B) CD43, CD5, CD11b classification methods. The proportion of each $\mathrm{B}$ cell subset within the total $\mathrm{CD} 2 \mathrm{O}^{+} \mathrm{B}$ cell population (left panel), A-specific $\mathrm{CD} 2 \mathrm{O}^{+} \mathrm{B}$ cells (middle panel), and blood group A-specific B cells among each B cell subset (right panel) were compared between peripheral blood and peritoneal cavity. The results are expressed as mean \pm SEM; $N=15-30$ per group.

${ }^{*} P<0.05,{ }^{*} P<0.01$ comparing between peripheral blood and peritoneal cavity.

Abbreviations: MZB, marginal zone B cells; MZ-B1, marginal zone-B1 cells; SEM, standard error of the mean.

CD11b- B1 cells, which contributes to the proliferation of T cells in systemic lupus erythematosus patients [10]. Considering the ability of $\mathrm{B} 1$ cells to promote $\mathrm{T}$ cell proliferation by interacting with $T$ cells, it is likely that $C D 11 b^{+} B 1$ cells will be activated with the help of T cells. Our previous study has shown that CD49d high CD4 ${ }^{+} T$ cells can help B1 cells secrete IgM and IgG [20]. Therefore, with the help of T cells, CD11 b $\mathrm{b}^{+} \mathrm{B} 1$ cells are likely to secrete anti-A antibodies.

Our study had a few limitations. First, we assessed blood group A-specific $B$ cells by counting $B$ cells that could bind to the A antigen. However, we were unable to confirm whether these cells could actually produce anti-A antibody specifically. As the proportion of B1 cells was very low in the peripheral blood, it was difficult to isolate them and perform functional analysis for antibody production against the A antigen. However, there was a strong correlation between the frequency of blood group A-specific $B$ cells and anti-A antibody titer, and these findings support the functional significance of blood group A-specific B cells indirectly. Second, the peritoneal cells were isolated from initial washing fluid from peritoneal dialysis patients instead of healthy 
individuals because of practical difficulties. No significant differences were observed between the B cell subsets in the peripheral blood of peritoneal dialysis patients and healthy volunteers (data not shown); therefore, we hypothesize that the peritoneal B cell composition might not significantly differ between the two populations. Third, we did not evaluate the correlation between blood group B-specific B cells and anti-B antibody titers. Further studies are necessary to extend the current findings to blood group B-specific B cells. Finally, the $\mathrm{R}$ values were generally low in this small-scale study; therefore, this correlation should be confirmed in further studies using independent validation sets with a larger sample size.

Nonetheless, this study confirmed the importance of B1 cells in anti-blood group antibody response, using two different classification systems, and demonstrated moderate correlations between the frequency of $\mathrm{B} 1$ cells and anti-ABO antibody titer for the first time. Therefore, B1 cells could constitute a potential therapeutic target for desensitization in $\mathrm{ABO}$-incompatible transplantation.

\section{Author Contributions}

All authors have accepted their responsibility for the entire content of this manuscript and approved submission.

\section{Conflicts of Interest}

No potential conflicts of interest relevant to this article were reported.

\section{Research Funding}

This study was supported by the Bio and Medial Technology Development Program of the NRF funded by the Ministry of Science and ICT (NRF-2015M3A9D3051413).

\section{ORCID}

$\begin{array}{ll}\text { Yixuan Xu } & \text { https://orcid.org/0000-0002-6039-2267 } \\ \text { Jae-Ghi Lee } & \text { https://orcid.org/0000-0002-0123-9801 } \\ \text { Ji-Jing Yan } & \text { https://orcid.org/0000-0002-4048-1406 } \\ \text { Jung-Hwa Ryu } & \text { https://orcid.org/0000-0003-1887-7823 } \\ \text { Songji Xu } & \text { https://orcid.org/0000-0003-0678-198X } \\ \text { Jaeseok Yang } & \text { https://orcid.org/0000-0002-5378-7797 }\end{array}$

\section{REFERENCES}

1. Morath C, Zeier M, Döhler B, Opelz G, Süsal C. ABO-incompatible kidney transplantation. Front Immunol 2017;8:234.

2. Okumi M, Toki D, Nozaki T, Shimizu T, Shirakawa H, Omoto $\mathrm{K}$, et al. ABO-incompatible living kidney transplants: evolution of outcomes and immunosuppressive management. Am J Transplant 2016;16:886-96.

3. Segev DL, Gentry SE, Melancon JK, Montgomery RA. Characterization of waiting times in a simulation of kidney paired donation. Am J Transplant 2005;5:2448-55.

4. Mond JJ, Lees A, Snapper CM. T cell-independent antigens type 2. Annu Rev Immunol 1995;13:655-92.

5. Tazawa H, Irei T, Tanaka Y, Igarashi Y, Tashiro H, Ohdan H. Blockade of invariant TCR-CD1d interaction specifically inhibits antibody production against blood group A carbohydrates. Blood 2013;122:2582-90.

6. Irei T, Ohdan H, Zhou W, Ishiyama K, Tanaka Y, Ide K, et al. The persistent elimination of $B$ cells responding to blood group $A$ carbohydrates by synthetic group A carbohydrates and B-1 cell differentiation blockade: novel concept in preventing antibody-mediated rejection in ABOincompatible transplantation. Blood 2007;110:4567-75.

7. Zhou W, Ohdan H, Tanaka Y, Hara H, Tokita D, Onoe T, et al. NOD/SCID mice engrafted with human peripheral blood lymphocytes can be a model for investigating B cells responding to blood group A carbohydrate determinant. Transpl Immunol 2003;12:9-18.

8. Hardy RR. B-1 B cell development. J Immunol 2006;177:2749-54.

9. Griffin DO, Holodick NE, Rothstein TL. Human B1 cells in umbilical cord and adult peripheral blood express the novel phenotype CD20+ CD27+ CD43+ CD70-. J Exp Med 2011;208:67-80.

10. Griffin DO and Rothstein TL. A small CD11b(+) human B1 cell subpopulation stimulates T cells and is expanded in lupus. J Exp Med 2011; 208:2591-8.

11. Verbinnen B, Covens K, Moens L, Meyts I, Bossuyt X. Human CD20+ CD43+CD27+CD5- B cells generate antibodies to capsular polysaccharides of Streptococcus pneumoniae. J Allergy Clin Immunol 2012;130:272-5.

12. Xu H, Sharma A, Lei Y, Okabe J, Wan H, Chong AS, et al. Development and characterization of anti-Gal B cell receptor transgenic Gal-/- mice. Transplantation 2002;73:1549-57.

13. Weill JC, Weller S, Reynaud CA. Human marginal zone B cells. Annu Rev Immunol 2009;27:267-85.

14. Weller S, Braun MC, Tan BK, Rosenwald A, Cordier C, Conley ME, et al. Human blood IgM 'memory' B cells are circulating splenic marginal zone B cells harboring a prediversified immunoglobulin repertoire. Blood 2004; 104:3647-54.

15. Wolfram W, Sauerwein KM, Binder CJ, Eibl-Musil N, Wolf HM, Fischer MB. Pneumococcal polysaccharide vaccination elicits IgG anti-A/B blood group antibodies in healthy individuals and patients with type I diabetes mellitus. Front Immunol 2016;7:493.

16. Akoglu H. User's guide to correlation coefficients. Turk J Emerg Med 2018;18:91-3

17. Koo TY and Yang J. Current progress in ABO-incompatible kidney transplantation. Kidney Res Clin Pract 2015;34:170-9.

18. Aziz M, Holodick NE, Rothstein TL, Wang P. The role of B-1 cells in inflammation. Immunol Res 2015;63:153-66.

19. Quách TD, Rodríguez-Zhurbenko N, Hopkins TJ, Guo X, Hernández AM, Li W, et al. Distinctions among circulating antibody-secreting cell populations, including B-1 cells, in human adult peripheral blood. J Immunol 2016;196:1060-9.

20. Lee JG, Jang JY, Fang T, Xu Y, Yan JJ, Ryu JH, et al. Identification of human B-1 helper T cells with a Th1-like memory phenotype and high integrin CD49d expression. Front Immunol 2018;9:1617. 